\title{
Adichie's Thematic Construction of a Post-Colonial Nigerian Nation-State in Two Excerpts from Her Purple Hibiscus: An Experiential Meaning Scrutiny
}

\author{
Dr. Daniel T. Yokossi
}

\author{
Prof. Léonard A. Koussouhon
}

Doi: $10.2478 / \mathrm{mjss}-2018-0008$

\begin{abstract}
This article digs into Adichie's world view of the post-colonial Nigeria via her use of the English language in two extracts culled from her Purple Hibiscus. To go into details, the study examines how Adichie makes use of particular types of transitivity patterns to weave into her text her thematic construction of Nigeria after independence. To this end, the Experiential Meaning has been used as a theoretical lens given that the exploration of the transitivity properties in/of a text can provide a full insight into how the writer encodes his/her experience of the world therein as advocated by Systemic Functional Linguistics scholars like Halliday (1971/1976), and his followers Hassan (1985/1989), Eggins (2004), and Matthiessen (2004/2006). As a matter of fact, the study offers a linguistic analysis of the selected extracts, a summary of the findings, and the ensuing interpretation. Actually, the interpretation of the findings has revealed that Adichie has encoded tremendous meanings through her outstanding use of such process types as material, mental and verbal processes. The distribution of these key processes in the analyzed extracts per participant has also highlighted both some of the author's key characters and to what extent these latter ones embody her perceptions of the social, religious and political issues that she artistically tries to castigate in her novel under examination. The study ultimately opens up to further explorations embracing such other fields of the Systemic Functional Linguistics as the interpersonal and textual meanings.
\end{abstract}

Keywords: Experiential meaning, SFL, Process types, Participants, Ideational metafunction

\section{Introduction}

Many African nations have disappointedly failed to successfully run themselves after their independences; Nigeria being one of them. This state of affairs has for a number of years now been the concern of many Nigerian elitist writers who are making every endeavor to express, via their fictional writings, their desolation about the desperate running of their countries by their political leaders. In fact, they do not just content themselves with denouncing or castigating the political governance of their nation, but they also make recommendations aiming at improving the running of the country in view of establishing a sustainable development. But their language use is so coded and imperceptible to the lay people that it requires further studies to be deeply understood. One way to arrive at this is to carry out linguistic analyses. As a matter of fact, this research aims at decoding the language use of one of the Nigerian new millennium writers; Chimamanda Ngozi Adichie, whose Purple Hibiscus is going to serve as a primary source in this study. To descend to particulars, two extracts from the above mentioned novel have purposefully been selected and analyzed in the light of the experiential meaning theoretical framework to witness how Adichie has linguistically encoded meanings therein, and, drawing on these latter ones, emphasize her ideological world view of the post-colonial Nigeria. The study is ultimately going to construe the 
findings of the analysis to make Adichie's messages to her Nigerian contemporaries in particular, and her African ones by extension, stand out more clearly in order to appraise to what extent her novel under scrutiny contributes to getting both Nigeria and Africa out of the rut so as to favor their development.

\section{Methodology of the Study}

This article aims at decoding the language use of Adichie in Purple Hibiscus to disclose her ideological world view of the post-colonial Nigeria. To attain this purpose, I have drawn upon the sampling and practical statistics methodology. More specifically, two excerpts that fall in with transitivity patterns analysis have been chosen and analyzed basing on the up-to-date experiential meaning analysis theories and keys within the SFL framework. Following the quantitative method, statistics of the data collected from the analysis have been drawn not only for the classification and counting of the excerpts linguistic features but also to pave the way for the qualitative method which has provided avenues to the discovery of deepest levels of the studied excerpts meanings via the findings interpretation.

\section{An Account of the Experiential Meaning}

To begin with, there are three metafunctional lines of meaning namely the experiential, the interpersonal and the textual. As Halliday and Mathiessen (2004:168) advocated, these metafunctional lines are unified within the structure of a clause. However, this article focuses on the experiential meaning. In fact, what is it actually all about?

Experiential meaning also referred to as ideational metafunction, (Eggins,1994), has to do with grammatical resources for constructing people's theories of experience, and how people construct reality in ways that seem natural to them. According to Halliday (1971:327), "the ideational metafunction is the function through which the speaker or writer embodies in language his experience of the phenomena of the real world: and this includes his experience of the internal world of his own consciousness: his reactions, cognitions and perceptions and also his linguistic acts of speaking and understanding." As well, Halliday and Mathiessen (2006) consider the experiential meaning as one that reflects the contextual value of "field", through participants, circumstances, and process (material, mental, behavioural, relational, verbal and existential) types. In fact, it is viewed as a theory of reality and a resource for reflecting on the world.

Actually, looking further at the metafunctions and their structural realizations, the ideational metafunction has two sub-categories namely the experiential sub-category and the logical one (Halliday \& Mathiessen, 2004, p.29). In fact, the experiential function is responsible, as suggested above, for expressing the happenings, the content - real or unreal - of experiences, and can be initially understood through such questions as: who is doing what to whom, where and when. At a more delicate level researchers examine different types of meanings that are achieved through what is called the transitivity system, a structural term to account for how processes, participants and circumstances, which make up the experiential sub-function, are realized. It permits a speaker or writer to express the ways in which the world of experience is represented and is conveyed through different process types such as material or action, mental and relational, as well as the different participants and circumstances involved in each of them (Halliday, 1994, p. 107). As for the logical sub-system, it mainly deals with ways in which clauses are connected to each other. First, they are connected through 'a system that describes the type of interdependency between clauses'. Second, 'the logico-semantic system describes the type of meaning relationship between linked clauses' (Eggins, 2004: 258-9).

In the present article, emphasis is laid on the ideational metafunction through its transitivity patterns that serve as a backdrop to the grammar of the experiential meaning.

\section{Transitivity Analysis of the Selected Excerpts}

As said earlier, the two excerpts analyzed here have been culled from Purple Hibiscus (2003) by 
Chimamanda Ngozi Adichie. In fact, the analysis has been carried out drawing on Eggins (2004) and Koussouhon (2009). More specifically, each of the selected excerpt has been divided into its constituent clauses be they finite or non-finite. Next, the processes identified in each clause have been counted. The following statistical table account for the number of processes identified per excerpt and on aggregate in both excerpts taken together after analysis.

Table1: Statistical summary of the number of processes recorded in the selected excerpts, (appendix: 18-24)

\begin{tabular}{|c|c|c|c|c|c|}
\hline \multicolumn{3}{|l|}{ Process types } & Excerpt $\mathrm{N}^{\circ} 1$ & Excerpt $\mathrm{N}^{\circ} 2$ & Excerpts $\mathrm{N}^{\circ} 1 \& \mathrm{~N}^{\circ} 2$ \\
\hline \multirow{2}{*}{\multicolumn{2}{|c|}{ Material processes }} & Effective/transitive & 41[28.47\%] & $18[14.51 \%]$ & $59[23.13 \%]$ \\
\hline & & \begin{tabular}{|l|} 
Middle/intransitive \\
\end{tabular} & $32[22.22 \%]$ & $13[10.48 \%]$ & $45[17.64 \%]$ \\
\hline \multicolumn{3}{|l|}{ Mental processes } & $07[04.86 \%]$ & $14[11.29 \%]$ & $21[08.23 \%]$ \\
\hline \multicolumn{3}{|c|}{ Behavioural Processes } & $19[13.19 \%]$ & $17[13.70 \%]$ & $36[14.11 \%]$ \\
\hline \multicolumn{3}{|l|}{ Verbal Processes } & $12[08.33 \%]$ & $28[22.58 \%]$ & $40[15.68 \%]$ \\
\hline \multirow{6}{*}{ Being Processes } & \multicolumn{2}{|c|}{ Existential Processes } & $01[0.69 \%]$ & $02[1.61 \%]$ & $03[01.17 \%]$ \\
\hline & \multirow{5}{*}{$\begin{array}{l}\text { Relational } \\
\text { Processes }\end{array}$} & Attributive processes & $18[12.50 \%]$ & $12[09.67 \%]$ & $30[11.76 \%]$ \\
\hline & & Identifying processes & $08[05.55 \%]$ & $04[03.22 \%]$ & $12[04.70 \%]$ \\
\hline & & Circumstantial processes & $02[1.38 \%]$ & $01[0.80 \% \%]$ & $03[01.17 \%]$ \\
\hline & & Possessive processes & $02[1.38 \%]$ & $01[0.80 \%]$ & $03[01.17 \%]$ \\
\hline & & Causative Circumstantials & $02[1.38 \%]$ & $01[0.80 \%]$ & $03[01.17 \%]$ \\
\hline \multicolumn{3}{|c|}{ Total number of processes recorded } & $144[100 \%]$ & $124[100 \%]$ & $255[100 \%]$ \\
\hline
\end{tabular}

A glimpse at the above statistical summary table gives an overview of all the transitivity features displayed in the two analyzed excerpts. A careful consideration of the results obtained, shows that each of the studied excerpts from the novel under study embeds all the process types of the SFL theoretical framework. The most frequently occurring processes in the overall excerpts are not only the material ones but also the verbal, the behavioural, the mental and the relational processes of the intensive attributive sub-type. In these prevailing categories, material processes are noticeably head and shoulders over the others with an aggregate number of a hundred and four (104) processes representing $40.78 \%$ of the overall two hundred and fifty-five (255) processes recorded in the two studied excerpts taken together. This actually suggests that both excerpts are actionpacked. Relational processes rank second, 32 in the first excerpt (12.54\%), and 19 in the second excerpt $(07.45 \%)$. Crudely speaking, the two excerpts count a global number of fifty-one (51) viz. $20 \%$ of the overall recorded processes. Whether in the first or second excerpt, the intensive attributive processes, [30] (11.76\%), followed by the intensive identifying processes, [12] (04.70\%) in the ranking order, dominate the relational category. This entails that both excerpts are significantly concerned with the description and definition of the social evils castigated by the author in her piece of prose fiction. Verbal processes come third with a total number of forty (40) processes that is to say $15.68 \%$ of the recorded processes. This indicates that the author has got some of her characters to express the social facts she has dealt with in her novel under study verbally. Coming next in the ranking order are the behavioural processes, [19] in the first excerpt and [17] in the second one viz. a total of thirty-six (36) processes on aggregate representing $14.11 \%$. Their use in the studied excerpts at this rate suggests that the texts are considerably concerned with the physiological and psychological moods of the conscious participants involved. Mental processes rank last but one with a number of 07 in the first excerpt and 14 in the second one that is to say 21 processes in total i.e. a percentage of $08.23 \%$ of the overall recorded processes. This is the evidence that the conscious participants as introduced to the reader in these excerpts under scrutiny are cognitively, affectively and intellectually involved in the matters dealt with by the author. The existential processes rank last with a total number of three (03) in both excerpts i.e. one (01) in the first one and two in the second one as shown by the above statistical table. The existents in the three existential processes are non-human or non-conscious beings which suggests that the facts being talked about here are really taking place in a real existing setting which is but the author's country. 


\section{Interpretation of the Findings}

This section provides a deeper understanding of Chimamanda Ngozi Adichie's Purple Hibiscus being scrutinized via the two excerpts culled from it by focusing on the interpretation of the findings. Indeed, I am not going to carry out a linear interpretation all the more as not all the linguistic features can be interpreted. In actual fact, I am going to focus on the overriding features in both studied excerpts that encode deep meanings for the general messages conveyed by Adichie in her novel under study. Consequently, the interpretation is going to revolve round the material, the mental, and the verbal process types along with their respective participants and circumstances.

As a matter of fact, out of the grand total of two hundred and fifty-five processes recorded in the two excerpts from Adichie's Purple Hibiscus, the material processes all alone amount to one hundred and four; nearly half of the overall processes embedded in the excerpts. Knowing that material processes are processes about concrete and tangible actions, their predominance in these two excerpts from Adichie's Purple Hibiscus is then symbolic of the author's perspective to prioritize pragmatic and realistic actions in this critical period of the novel's background when violence, corruption, embezzlement, Power abuse, despotism, religious fanaticism and dogmatism together with the state coffers plundering were the most widespread prevailing evils.

In other respects, a look at the statistical table presented above discloses that there are fortyone (41) effective material processes in the first excerpt representing $28.47 \%$ of the overall processes embedded in it, while the intransitive material processes are thirty-two (32) in total with a percentage of $22.22 \%$. As a matter of fact, some of the effective material processes enclosed in the excerpt can be witnessed in clauses $5,17,19,22,23,24,25,38,40,49,50,54,57,58,68,70$, $72,73,83,92,93,94,96,98,103,106,109,117,126$, of the analysis carried out in the appendix of this article. A careful look into these transitive material processes reveals that most of them are achieved by such characters as Kambili Achike, Eugene Achike( called Papa here in the excerpt), Jaja and Beatrice (called mama in the excerpt). To descend to particulars, Kambili alone performed nineteen (19) of the transitive material processes. As for Papa, he achieved nine (09) of them. Next, Jaja comes in performing five (05) of them and Mama four (04). The remaining four (04) transitive actions have been performed by Achike's family altogether. This indirectly implies that Adichie's message in this excerpt is centered on Achike's family which is but just a depiction of what Adichie's society looks like in this period of time. A closer look into the number of actions performed by each of the characters in the excerpt reveals that the female characters have achieved more than the male characters when taken together on each side. For instance, Kambili and Mama achieved twenty-three (23) of the whole processes whereas Papa and Jaja performed just fourteen (14) of them all. This in fact calls to mind Adichie's feminism. Via this linguistic construct, Adichie is certainly inviting her contemporary females to concrete actions in order to contribute to changing the evil course of things in her society. This indirectly implies that Adichie believes in female gender's capacity to set everything to the move and boost positive changes. That is undoubtedly why she has allowed her key female character Kambili Achike, the omniscient narrator, to perform most of the transitive action processes in the excerpt.

Through the actions performed by Eugene Achike i.e. Papa in the excerpt, Adichie is certainly showing how fanaticism can be monstrous and deadly. Even Jesus-Christ himself was not that so fanatic. In the Bible especially in the Gospel of Luke 14: 1-6 we read about Jesus-Christ healing a sick man on the Sabbath. Although Jesus-Christ knew that healing on the Sabbath was something strictly proscribed by Moses's law, he did it because it was urgent and necessary for the sick man to continue living .But in the excerpt in hand; Papa would not understand why Mama could allow Kambili to eat ten minutes before mass on the Eucharistic fasting Sunday. By allowing Kambili, Mama and Jaja to transgress the Eucharistic fast, Adichie is certainly conveying the crucial message that Christendom has nothing to do with religiosity and that Christians should serve God wisely with proper judgment, not blindly and fanatically.

The intransitive material processes of this first excerpt are also those of concrete actions. Some of them can be found in clauses $3,4,9,11,20,37,46,48,52,53,59,63,84,85,86,87$, 90,107 , and 144. Indeed, the actor roles are played by the same personae pinpointed above. The distribution of these intransitive material processes per character in the excerpt shows that Kambili 
performed most of the intransitive actions. More specifically, while Papa achieved only three (03), Jaja just one (01) and Mama just two (02), Kambili achieved all alone twelve (12) of them. The four remaining intransitive processes have been achieved by Achike's family altogether. Here Again, majority of the doings (fourteen on the whole) have been achieved by the female characters, which, as said earlier, is revelatory of Adichie's feminism. In other respects, these processes are those in which the actions of the actors are not extended to other participants but are rather reduced to themselves. Obviously, this connotes that Nigerians are the solutions to their own problems and that they should not keep passively sitting down with their arms crossed expecting solutions to come from elsewhere or God to work out miracles for them. In other respects, both the transitive and intransitive material processes in the excerpt express concrete actions performed by conscious human beings. This in fact suggests that human beings are the only expected beings to work out the needed radical changes. Indirectly, Adichie is conveying the message that Nigerians have to stand up as one man to block the way to these negative trends otherwise neither the Almighty God nor even their lesser worshiped gods can operate any change whatever their degree of spirituality.

A switch to the second excerpt accounts for a total number of thirty-one (31) material processes. Here again, material processes are noticeably head and shoulders over the other process types. Indeed, out of the thirty- one material processes, eighteen-18- are effective and almost even-handedly, the remaining thirteen-13- others are middle. Some of the transitive material processes can be witnessed in clauses 1, 40, 49, 85, and 112 of the analysis carried out in the appendix. As a matter of fact, they also express concrete and tangible actions carried out by human beings playing the Actor roles. These concrete and tangible actions from conscious participants exemplify not only that the author is depicting a real social fact, but also that whatever claim is being lodged via her writing can only get achieved by human beings, be they men or women. Moreover, the actions of the human participants playing the Actor roles are directed to either animate or inanimate beings such as: "the plantains" and "you" a referent to Father Amadi. This in fact, suggests that the human participants in the excerpt are expected to make use of any means to reach their goals. Indeed, all the clauses that involve human subjects are ones in which such Actors as Eugene Achike, Kambili, Jaja Beatrice (Mama), and Father Amadi act on something external to them. This shows the necessity for interaction and cooperation for the expected triumph over the evils Adichie and her contemporaries were suffering from. Adichie is certainly calling attention to the necessity for her contemporaries to stop acting selfishly, and look at the general interest of the whole Nigerians for a total recovery of the country from its devastating evils on the one hand, and for a harmonious and perfect development of the overall nation on the other. Further, through the Goals of the compound transitive material process in the hundred and twelfth clause of this excerpt Chimamanda, is inviting her contemporaries not to set forth theories but to take concrete and highly valuable actions in the struggle against both the poor widespread leadership and the rampant government corruption prevailing in her country viz. the post-colonial Nigeria.

As for the middle material processes, they represent nearly half of the total number of material processes embedded in the excerpt and are about concrete actions as well. Indeed, eight-08- out of the thirteen-13- intransitive material processes describe movement. These involve such verbs as: "drove, came back, returned, go, get out etc" and nine-09- out of these intransitive movement processes specify distinct location circumstances especially of spatial sub-type. Examples would involve clauses $21,27,55$, and 65 . Indeed, this state of affairs suggests that Chimamanda's novel depicts realities relating to a specific place which here is Nigeria her native country; and possibly Africa by extension. It is to be underlined that one of the intransitive material processes enclosed in this excerpt describes immobility although the Actor role is played by a human being. That process is exemplified in clause 109. This suggests that by the time this fiction was being written, Adichie's contemporaries were not actually facing their diverse responsibilities as they should; and that the author, through her writing, is calling upon them for a change in their passive attitude for a better upcoming future. More revealing, the tense of the process highlights that the unwelcoming attitude the author is castigating is a usual fact. But Adichie, through her linguistic choice here, is reproving such manners and would like her contemporaries to understand that, to be successful in the fight of bringing her country out of the political, social, economic and socio-economic abyss it has fallen 
into, everyone has to chip in given that unity is strength.

Adichie's selection of the mental processes in her writing is also evocative of meaning. Indeed, of the 21 mental processes recorded in both excerpts, cognition mental processes which are ten (10) in number prevail over the other mental process sub-types. Their prevalence over the other mental process subtypes in the studied excerpts suggests that Adichie would like her contemporaries to become conscious of, and learn from the evils prevailing by the severe stressful period they were going through, and think of sustainable solutions so that Nigeria can systematically get cured of its social scourges once for all. The very low distribution of the affection mental processes (03) is symbolic of what might be the cause for all the turmoil going on in the time: lack of love. When love misses, selfishness, violence, animosity and misunderstanding, to make a long story short, settle. And those were the real evils Nigerians were suffering from. The eight (08) perception mental processes indicate that both Adichie and some of her contemporaries were acutely aware of the fact and would like the other fellow citizens to rally for better sociopolitical living conditions. Truly, a community without love can neither progress nor prosper.

Adichie's message via the numerous verbal processes (40 on aggregate) occurring in the excerpts understudy is crystal clear. A careful look into their distribution in the first excerpt reveals that Mama carried out four (04) verbal actions as it can be witnessed in clauses 16, 55, 89, and 127; Papa three in clauses 118, 134, and 141; Jaja two in clauses 67, and 91; Kambili one in clause 137; Father Benedict one in clause 28 and the devil one too in clause 95. This distribution of the verbal processes in the excerpt indicates that Mama has carried out more verbal actions than the other participants. As a matter of fact, any reader of Purple Hibiscus might be surprised that Mama is performing the most important part of the verbal actions here since Adichie has introduced her to the reader in this novel as a quiet and submissive woman. In fact Adichie is certainly conveying through this linguistic construct that women should not continuously be subjected to men or unceasingly reduced to silence in African societies. She is further certainly inviting these African women not to withdraw into total silence, but to stand up and say stop to injustice, ill-treatment and men's misuse of authority over them so as to contribute to the improvement of the social standards of their societies for the development of their countries in particular and continent by and large.

The use of verbal processes in the second excerpt is also particularly full of meanings. In fact, in the excerpt, we witness, Father Amadi, Amaka, Obiora, Papa Nnukwu and Aunty Ifeoma( Key personae of the excerpt) discussing about religion and oppression with Papa Nnukwu telling Father Amadi what he as a priest should do and what he shouldn't do though not any Christian. This suggests that one way out of all the evils Nigerians were suffering from being suggested by Adichie, through the verbal properties of this excerpt in that period of time, could be dialogue among citizens of different classes in the country. People from different political tendencies should come together over the common issues of development of the nation as the Pagan Papa Nnukwu and Father Amadi are exchanging ideas about religion here in the second excerpt though not of the same religious persuasion. Conclusions should be drawn and recommendations made at the end of these discussions as regards the rebuilding of the country and enforced without any bias or prejudice.

The circumstances attending the processes identified in the excerpts from Adichie's Purple Hibiscus are basically those of manner, location, cause, and extent showing the crucial degree at which the evils undermining Nigerian people as mentioned earlier is, and suggesting ways to get out of them all for a brighter future.

\section{Conclusion}

Aimed at decoding the language use of Chimamanda Ngozi Adichie, in Purple Hibiscus, to disclose her ideological world view of the post-colonial Nigeria, the present article has used the experiential meaning as a theoretical lens. Indeed, two sample excerpts have been culled from the author's novel under scrutiny to serve as the data stockpile for the study carried out in this article. The transitivity analysis of the two sample excerpts has allowed the study to record some key findings the interpretation of which has shed light on the messages of the author hidden between her text lines. Actually, the interpretation has been carried out around three process- types which the author has used in a particular way owing to their outstanding number after analysis. As a matter of fact, 
contrarily to what one would expect from a fifty-five-year old independent country in terms of social, economic and political development, the modern Nigeria is linguistically depicted here as one that is still sinking in such social evils as violence, corruption, embezzlement, Power abuse, despotism, religious fanaticism and dogmatism together with the state coffers plundering. The use of the material process-type by Adichie in this novel clearly shows the author's perspective, as regards the Nigerian elites, to prioritize pragmatic and realistic actions above everything else to get out of those above pinpointed evils. Indeed, the linguistic encoding of both the transitive and intransitive material processes has unveiled Adichie's feminism ingeniously hidden in her studied texts. One other striking message by Adichie through her linguistic coding of the material process-type is that Nigerians should join forces to get their country out of the devastating consequences of the neocolonialism undermining it. The linguistic encoding of the mental and verbal processes is basically meant to exude Adichie's invitation of her Nigerian contemporaries to consciousness and to an understanding melting pot among the multicultural groups for her country's political, social, and economic restoration. To round off, further investigations about the interpersonal and textual meanings in the same studied excerpts would not only help get to the core of the meanings embedded therein more deeply than ever, but they would also reveal other relevant fields of interest for future investigations.

\section{References}

Adichie, C. N. (2003). Purple Hibiscus, First Edition. Lagos: Farafina.

Brown,K.(2004).Encyclopedia of Language and Linguistics, Second Edition.Volume1, Elsevier: The Pergamon Imprint.

Butt, D., Fahey, R., Feez, S., Spinks, S. and Yallop, C. (2000) Using Functional Grammar: An Explorer's Guide, Sydney, Australia: National Centre for English Language Teaching and Research, Macquarie University.

Chapman, R. (1973). Linguistics and literary style. New York: Holt, Rinehart and Winston, Inc.

Cummings, M. \& Simmons, R. (1983). The Language of Literature: A Stylistic Introduction to the Study of Literature. Oxford: Pergamon Press. Ltd

Dik, C. S. (1989). The Theory of Functional Grammar. Partl: The Structure of the clause. Dordrecht: Foris Publications.

Eggins, S. (1994). An Introduction to Systemic Functional Linguistics. London: First Edition Printer Publishers.

Eggins, S. (2004). An Introduction to Systemic Functional Linguistics, (2nd ed.). New York \& London: Continuum.

Fowler, R. (1981). Literature as Social Discourse: The Practice of Linguistic Criticism. Oxford: Oxford University Press.

Halliday, M. A. K. ([1978] 1979) Language as a Social Semiotic: The Social Interpretation of Language and Meaning, London: Edward Arnold.

Halliday, M.A.K. (1983). The language of literature: A stylistic introduction to the study of literature. Oxford: Pergamon Press.

Halliday, M. A. K. (1985). An introduction to functional grammar. London: Edward Arnold.

Halliday, M.A.K. and Hasan,R. (1985/1989). Language, Context, and text: Aspects of Language in a socialsemiotic perspective. Oxford: Oxford University Press.

Halliday, M.A.K. (1994). An Introduction to Functional Grammar, (2nd ed). London: Hodder Arnold.

Halliday, M. A. K. (2002) Linguistic studies of text and discourse. London and New York: Continuum.

Halliday, M.A.K. (1971). "Linguistic Function and Literary Style: An Inquiry into the language of William Golding's The Inheritors" In S.B. Chatman(ed) (1971) Literary Style: A symposium (pp.330-368) London and New York: Oxford University Press.

Halliday, M. A. K. \& Matthiessen, C. M. I. M. (2004). An Introduction to Functional Grammar (3rd ed.). London: Hodder Education, and Hachette UK Company.

Halliday, M. A. K. \& Matthiessen, C. M. I. M. (2006). Construing Experience through meaning: A Languagebased Approach to cognition. London - New York: Continium

Halliday, M. A. K., \& Hasan, R. (1985). Language, context and text: aspect of language in a social-semiotic perspective Oxford: Oxford University Press.

Hasan, R. (1985). Linguistics, Language, and Verbal Art. Oxford: Oxford University Press.40.Matthiessen, C. (1995). Lexico-grammatical cartography: English systems. Tokyo:International Language Science Publishers.

Hadumod, B. (1996). Dictionary of Language and Linguistics, $\left(2^{\text {nd }}\right.$ ed). London and New York: Routledge 


\section{Appendix}

The Transitivity analysis of the two selected excerpts used as data in this article has been carried out drawing on the keys hereafter.

NB: The numerals following every single of the identified process type are meant to help draw up statistics accurately without any miscount.

$\mathrm{P}=$ Process; Pm=Material Process; Pme=Mental Process; Pb=Behavioural; Process, Pv=Verbal Process; $\mathrm{Pe}=$ Existential Process; $\mathrm{Pi}=$ Intensive Attributive/Identifying Process; Pcc=Circumstantial Process; $\mathrm{Pp}=$ Possessive Process; $\mathrm{Pc}=$ Causative Process; $\mathrm{A}=\mathrm{Actor} ; \mathrm{G}=\mathrm{Goal}, \mathrm{B}=$ Beneficiary, $\mathrm{R}=\mathrm{Range}$; $\mathrm{S}=$ senser, $\mathrm{Ph}=$ Phenomenon; Sy=Sayer; Rv=Receiver; Vb=Verbiage; Be=Behaver; Bh=Behaviour; $\mathrm{X}=$ Existent; $\mathrm{T}=\mathrm{Token}$; $\mathrm{V}=$ Value; $\mathrm{Cr}=$ Carrier; At=Attribute; Id= Identifie; Ir= Identifier; Pr=Possessor; Pd=Possessed; C=Circumstance; $\mathrm{Cl}=$ location; $\mathrm{Cx}=$ extent; $\mathrm{Cm}=$ manner; $\mathrm{Cc}=$ cause; $\mathrm{Ca}=$ accompaniment; $\mathrm{Ct}=$ matter; $\mathrm{Co}=\mathrm{role}$; $\mathrm{Re}=\mathrm{recipient}$; Ag=Agent.

\section{Excerpt N¹: From Purple Hibiscus, by Chimamanda Ngozi Adichie, (Pp108-111)}

1. The next day (Id/T) was (Pi1) a Sunday (Ir/V). 2. It $(\mathbf{C r})$ did not seem (Pi1) like a Sunday (At), maybe 3.because we $(\mathbf{A})$ had just gone $(\mathbf{P m} 1)$ to church on Christmas day (Cl). 4.Mama (A) came into (Pm2) my $\operatorname{room}(\mathbf{C l}) / /$ 5.and shook $(\mathbf{P m} 3) \operatorname{me}(\mathbf{G})$ gently $(\mathbf{C m})$, //6.hugged(Pb1) me(Ph),//7. and I(Be) smelled(Pb2) her mintscented deodorant(Ph).

8."'Did you(Be) sleep(Pb3) well?(Cm) 9.We(A) are going(Pm4) to the earlier Mass today $(\mathbf{C l})$ 10. because your father(Cr) has(Pi2) a meeting $(\mathbf{A t})$ right afterwards $(\mathbf{C l}) .11$. Kunie(A), get(Pm5) into the bathroom(Cl), 12.it(Id/T)'s(Pi2) past seven.(Ir/V))"

13.I(Be) yawned(Pb4)// 14.and sat up(Pb5). 15. There was $(\mathbf{P e 1})$ a red stain $(\mathbf{X})$ on my bed $(\mathbf{C I})$, wide as an open notebook (at).

16. "Your period," (Vb) Mama said (Pv1). 17. "Did you (A) bring (Pm6) pads?(G)"'(Vb)

18."Yes"'(Vb)

19.I(A) barely let the water $(\mathbf{G})$ run $(\mathbf{P m 7})$ over my body $(\mathbf{C I})$ 20.before I(A) came out(Pm8) of the shower(CI), 21.so that $\mathrm{I}(\mathbf{C r})$ would not delay(Pi3).22.I(A) picked out(Pm9) a blue-and-white dress(G)//23. and tied(Pm10) a blue scarf(G) around my head(CI). 24.I(A) knotted(Pm11) it(G) twice(Cx) at the back of my neck(CI)// 25.and then tucked(Pm12) the ends of my cornrows(G) underneath(CI). 26.Once(Cx), Papa(Be) had hugged(Pb6) me(Ph) proudly(Cm),// 27.kissed(pb7) my forehead(Ph),// 28.because Father Benedict(Sy) told(Pv2) him(Rv) //29.that my hair(Cr) was(Pi4) always $(\mathbf{C x})$ properly $(\mathbf{C m})$ covered(At) for Mass(Cc), //30.that I(Id/T) was(Pi3) not like the other young girls(Ir/V) in church(CI)// 31.who(Be) let(Pb8) some of their hair show $(\mathbf{P h}), 32 . a s$ if they(S) did not know(Pme1)//33. that exposing(Pb9) your hair(Ph) in church(Cl)34. was (Pi5) ungodly $(\mathbf{A t})$.

35.Jaja and Mama (Cr) were (Pi6) dressed (At)// 36.and waiting (Pcc1) in the living room upstairs $(\mathbf{C l})$ 37.where I(A) came out(Pm13). 38. Cramps (A) racked (Pm14) my belly (G). 39.I(S) imagined (Pme2) //40.someone (A) with buckteeth rhythmically $(\mathbf{C m})$ biting(Pm15) beep(G) into my stomach walls $(\mathbf{C l}) / / 41$. And letting go(Pm16). 42.Do you(Pr) have(PP1) Panadol(Pd), Mama?(Vb)"

43."Cramps abia?"'(Vb)

44."Yes. My stomach (Cr) is (Pi7) so empty (At), too. "

45.Mama (Be) looked at (Pb10) the wall clock, a gift from a charity (Ph)// 46.Papa $(\mathbf{A})$ donated to (Pm17), oval shaped and embossed with his name in gold lettering( $\mathbf{C m}) .47 . \mathrm{It}(\mathbf{I d} / \mathbf{T})$ was(Pi4) 7:37(Ir/V). 48.The Eucharist fast(A) mandated(Pm18)// 49.that the faithful(A) not eat(Pm19) solid food(G) an hour before $\mathbf{M a s s}(\mathbf{C l})$. 50.We(A) never broke(Pm20) the Eucharistic fast(G); 51.the table(Cr) was(Pi8) set(At) for breakfast(Cc) with teacups and cereal bowls side by $\operatorname{side}(\mathbf{C m})$, //52.but we $(\mathbf{A})$ would not eat(Pm21) //53.until we $(\mathbf{A})$ came $(\mathbf{P m} 22)$ home(Cl).

54."Eat (Pm23) a little corn flakes (G), quickly (Cm),"55.Mama (Sy) said (Pv3) almost in a whisper (CI). 56.You (Pr) need (Pp2) something (Pd) in your stomach (CI)// 57.to hold (Pm24) the Panadol.(G)"'

58.Jaja (A) poured $(\mathbf{P m} \mathbf{2 5})$ the cereal $(\mathbf{G})$ from the carton on the table $(\mathbf{C I}), / / 59$. scooped $(\mathbf{P m} \mathbf{2 6})$ in powdered milk and sugar $(\mathbf{C l})$ with a teaspoon $(\mathbf{C m})$, //60.and added $(\mathbf{P m} 27)$ water $(\mathbf{G})$. 61. The glass bowl $(\mathbf{C r})$ was $(\mathbf{P i 9})$ transparent (At), // 62.and I(S) could see (Pme3) the chalky clumps (Ph)// 63.the milk $(\mathbf{A})$ made $(\mathbf{P m 2 8})$ with the water $(\mathbf{C m})$ at the bottom of the bowl $(\mathbf{C l})$.

64."Papa(Cr) is(Pcc2) with visitors(Ca), //65.we(S) will hear(Pme4) him(Ph)// 66.as he(A) comes up(Pm29)" 67.he(Sy) said(Pv4).

68.I(A) started to wolf(Pm30) the cereal(G) down, //69.standing(Pi10). 70.Mama(A) gave(Pm31) me(B) the Panadol tablets(G), still in the silver-coloured foil $(\mathbf{C m})$, 71.which $(\mathbf{C r})$ crinkled $(\mathbf{P i 1 1}) / / 72$.as $\mathrm{I}(\mathbf{A})$ opened(Pm32) it(G).73. Jaja(A) had not $\operatorname{put}(\mathbf{P m} 33)$ much cereal(G) in the bowl $(\mathbf{C l})$, $/ / 74$.and $\mathrm{I}(\mathbf{A})$ was almost done eating $(\mathbf{P m} 34)$ it(G)// 75. when the door(A) opened(Pm35)// 76.and $\mathrm{Papa}(\mathbf{A})$ came in(Pm36).

77.Papa's white shirt, with its perfectly tailored lines $(\mathbf{A g})$, did little to minimize $(\mathbf{P c 1})$ the mound of flesh $(\mathbf{C r}) / / 78$. that $(\mathbf{I d} / \mathbf{T})$ was $(\mathbf{P i 5})$ his stomach(Ir/V).79. While he(Be) stared at(Pb11) the glass bowl of corn flakes(Ph) in $\mathrm{my}$ 
hand(Cl),80. I(Be) looked down(Pb12) at the few flaccid flakes(Ph)// 81.floating(Pm37) among the clumps of milk(Cl)// 82.and wondered(Pme5) how $(\mathbf{C m}) / / 83$.he(A) had climbed(Pm38) the stairs(G) so soundlessly(Cm). 84."What are you(A) doing(Pm39), Kambili?"'(Vb)

85.I (A) swallowed (Pm40) hard (Cm). "I........."(Vb)

86."'You $(\mathbf{A})$ are eating $(\mathbf{P m} \mathbf{4 1})$ ten minutes before Mass? Ten minutes before Mass? $(\mathbf{C l})$

87."Her period (A) started (Pm42)//88. and she (Cr) has (Pi12) cramps-"(Vb) 89.Mama(Sy) said(Pv5).

90.Jaja(A) cut(Pm43) her(G) short. 91.I(Sy) told(Pv6) her(Rv)//92. to eat(Pm44) corn flakes(G)//93. before she(A) took(Pm45) Panadol(G), Papa. 94.I(A) made(Pm46) it(G) for her.(Cc)"'

95."Has the devil(Sy) asked(Pv7) you all(Rv)// 96.to go(Pm47) on errands(G) for him?(Cc)" 97.The Igbo words(Cr) burst out(Pi13) of Papa's mouth(Cl). 98. "Has the devil(A) built(Pm48) a tent(G) in my house?(Cl)" 99.He(A) turned(Pm49) to Mama.(G)

100. "You (Be) sit (Pb13) there (Cl)// 101.and watch (Pb14) her (Ph)//102. desecrate (Pm50) the Eucharistic fast (G), maka nnidi?(Vb)"

103. He(A) unbuckled(Pm51) his belt(G) slowly(Cm).104. It(Cr) was(Pi14) a heavy belt made of layers of brown leather(At) with a sedate leather-covered buckle $(\mathbf{C m})$.105. It(A) landed(Pm52) on Jaja first, across his shoulder(CI). 106.Then $\operatorname{Mama}(\mathbf{A})$ raised(Pm53) her hands(G)// 107.as it(A) landed(Pm54) on her upper $\operatorname{arm}(\mathbf{C l}), / / 108$.which $(\mathbf{I r} / \mathbf{V})$ was covered(Pi6) by the puffy sequined sleeve of her church blouse(Id/T). 109.I(A) put(Pm55) the bowl(G) down //110.just as the belt(A) landed(Pm56) on my back(CI). 111. Sometimes (Cx) I(A) watched(Pb15) the Fulani nomads(Ph),//112. white jellabas(A) flapping (Pm57)against their legs in the wind $(\mathbf{C l}), / / 113$. making(Pm58) clucking sounds(G)// 114.as they(A) herded(Pm59) their cows(G) across the roads in Enugu $(\mathbf{C I})$ with a switch, each smack of the switch swift and precise $(\mathbf{C m}) .115$. Papa(Id/T) was $(\mathbf{P i 7})$ like a Fulani nomad-(Ir/V)//116.although he(Cr) did not have(Pi15) their spare(At), tall body //117.as he(A) swung (Pm60) his belt(G) at Mama, Jaja, and me, (Cl)//118. muttering(Pv8) 119.that the devil(A) would not win(Pm61). 120.We (A) did not move (Pm62) more than two steps (Cx) away from (CI) the leather belt 121that $(\mathbf{A})$ swished (Pm63) through the air (CI).

122.Then the belt (A) stopped (Pm64), //123.and Papa (Be) stared (Pb16) at the leather (Ph) in his hand (Cl).124. His face (Cr) crumpled (Pi16); //125. his eyelids (Cr) sagged (Pi17).

126."'Why do you(A) walk into(Pm65) sin?(G)"(Vb) 127.he(Sy) asked(Pv9). 128.'Why do you(S) like(Pme6) $\sin ?(\mathbf{P h})$ "'(Vb)

129.Mama(A) took(Pm66) the belt(G) from him(Cl)//130. and laid(Pm67) it(G) on the table.(Cl)

131.Papa (A) crushed (Pm68) Jaja and me (G) to his body (CI). 132."'Did the belt (A) hurt (Pm69) you? (G) 133.Did it (A) break (Pm70) your skin? (G)" (Vb) 134.he (Sy) asked (Pv10), //135.examining (Pb17) our faces (Ph).136. I(S) felt(Pme7) a throbbing(Ph) on my back(Cl), //137.but I(Sy) said(Pv11) no(Vb), //138.that I(Cr) was not(Pi18) hurt(At).139. It(Id/T) was(Pi8) the way(Ir/V)// 140.Papa(Be) shook(Pb18) his head(Ph)// 141. when he(Sy) talked(Pv12) about liking $\sin (\mathbf{C t})$, //142.as if something(Ag) weighed (Pc2) him(Cr) down, //143.something(G) he(A) could not throw off(Pm71).

144.We (A) went (Pm72) to the later Mass (CI). 145.But first we (A) changed (Pm73) our clothes (G), even Papa, // 146.and washed (Pb19) our faces (Ph).

\section{Excerpt N²: From Purple Hibiscus, by Chimamanda Ngozi Adichi, (Pp 178-180)}

1.Amaka(A) picked up(Pm1) the plaintains(G)// 2.and pressed(Pm2) each(G) between her fingers(CI),// 3.as if she(S) would figure out(Pme1) //4.why they $(\mathbf{C r}) \operatorname{cost}(\mathbf{P i 1})$ so much(At) 5.by doing(Pm3) that(G). 6.She $(\mathbf{A})$ took $(\mathbf{P m} 4)$ them $(\mathbf{G})$ inside $(\mathbf{C l}) / / 7$.just as Father Amadi $(\mathbf{A})$ drove in $(\mathbf{P m 5}) / / 8$. and parked $(\mathbf{P m} 6)$ in front of the flat (Cl). 9. His windscreen $(\mathbf{A})$ caught $(\mathbf{P m} 7)$ the sun $(\mathbf{G}) / / 10$.and glittered $(\mathbf{P i 2})$. 11. He $(\mathbf{A})$ bounded up (Pm8) the few stairs $(\mathbf{G})$ to the verandah $(\mathbf{C l}), / / 12$.holding $(\mathbf{P m} 9)$ his soutane $(\mathbf{G})$ up like a bride holding a wedding dress $(\mathbf{C m})$. 13. He (Be) greeted (Pb1) papa-Nnukwu (Ph) first, //14.before hugging (Pb2) Aunty lfeoma (Ph)//15. and shaking $(\mathbf{P b} 3)$ hands $(\mathbf{P h})$ with the boys $(\mathbf{C a}) .16$. I(A) extended (Pm10) my hand (G) $/ / 17$.so that we $(\mathbf{A})$ could shake (Pm11), 18.my lower lip(Be) starting to tremble(Pb4).

19."Kambili(Vb)," he(Sy) said(Pv1), //20.holding(Pm12) my hand(G) a little longer than the boys'(Cm).

21."Are you (A) going (Pm13) somewhere (Cl), Father?(Vb)" 22.Amaka(Sy) asked(Pv2),//23. coming(Pm14) onto the verandah $(\mathbf{C l})$. 24."You $(\mathbf{A})$ must be baking $(\mathbf{P b 5})$ in that soutane $(\mathbf{C l}) . "$

25."I(A) am going over(Pm15) //26.to give(Pm16) some things(G) to a friend of mine(B),// 27.the priest who(A) came back(Pm17) from Papua New Guinea(Cl). 28. He (A) returns (Pm18) next week (CI)."

29."Papua New Guinea (Vb). 30.How did he (Sy) say (Pv3)// 31.the place (Cr) is (Pi3), eh?" (Vb) 32.Amaka (Sy) asked (Pv4).

33."He (Sy) was telling (Pv5) a story of crossing a river by canoe, with crocodiles right underneath (Vb). 34. He (Sy) said (Pv6)//35. he (Cr) is not (Pi4) sure (At) //36. which happened (Pi5) first (At), //37. hearing (Pme2) the teeth of the crocodiles snapping $(\mathbf{P h}) / / 38$. or discovering (Pme3)// 39.that he $(\mathbf{B e})$ had wet $(\mathbf{P b 6})$ his trousers (Ph)."

40."They $(\mathbf{A})$ had better not send $(\mathbf{P m} 19)$ you $(\mathbf{G})$ to a place $(\mathbf{C l})$ like that $(\mathbf{C m}), "(\mathbf{V b}) / /$ 41.Aunty Ifeoma(Sy) said(Pv7) with a laugh $(\mathbf{C m}), / / 42$.still fanning $(\mathbf{P m} 20)$ herself $(\mathbf{G}) / / 43$.and sipping(Pb7) from a glass of water(Cl). 
44."I(S) don't even want (Pme4) //45.to think (Pme5) about your leaving (Ct),

46. Father (Vb), "Amaka (Sy) said (Pv8).47."You (S) still don't have (Pme6) an idea (Ph) where and when (CI), okwia?

48."No. Sometime next year, perhaps (Cl)."

49."Who (A) is sending (Pm21) you (G)?" 50.Papa-Nnukwu (Sy) asked (Pv9), in his sudden way (Cm) //51.that (Ag) made (Pc1) me(Cr) //52.realize (Pme7)// 53.he (Be) had been following (Pb8) every word spoken in lgbo $(\mathrm{Ph})$.

54.- "Father Amadi (Id/T) belongs (Pi1) to a group of priests ndi missionary $(\mathbf{I r} / \mathbf{V}), / / 55$.and they $(\mathbf{A}) \mathrm{go}(\mathbf{P m} 22)$ to different countries(CI)// 56.to convert(Pm23) people(G),"(Vb) //57.Amaka(Sy) said(Pv10). 58.She (Sy) hardly peppered (PV11) her speech (G) with English words (Cm) //59.when she (Sy) spoke (Pv12) to Papa-Nnukwu (Rv), 60.as the rest of us (A) inadvertently did (Pm24).

61."Ezi okwu? (Vb)" 62.Papa-Nnukwu (Be) looked up (Pb9), his milky eye on Father Amadi (Cl).63."Is (Pi6) that $(\mathbf{C r})$ so $(\mathbf{C m})$ ? 64. Our own sons $(\mathbf{C r})$ now go to be(Pi7) missionaries(At) in the white man's land?(Cl)"

65."We (A) go (Pm25) to the white man's land and the black man's land (Cl), sir," (Vb) 66.Father Amadi (Sy) said (Pv13). 67."Any place (Cr) that needs (Pp1) a priest (At)" (Vb)

68."It (Cr) is (Pi8) good (At), my son. 69.But you (Sy) must never lie (Pv14) to them (Rv). 70.Never teach (Pv15) them (Rv) //71.to disregard (Pme8) their fathers (Ph)"72. Papa -Nnukwu (Be) looked away (Pb10),73. shaking (Pb11) his head (Ph).

74."Did you(S) hear (Pme9) that (Ph), Father?"(Vb) 75.Amaka (Sy) asked (Pv16)."76.Don't lie (Pv17) to those poor ignorant souls $(\mathbf{R v}) . "(\mathbf{V b})$

77."It (Cr) will be (Pi9) hard (At) not to, //78.but I (Sy) will try (Pv18)," (Vb) 79.Father Amadi (Sy) said (Pv19), in English (Cm).80. His eyes (A) crinkled (Pb12) at the corners (Cl) //81.when he (Be) smiled (Pb13).

82."You(S) know (Pme10), Father, 83.it(T)'s(pi2) like making okpa (V)," (Vb) 84.Obiora (Sy) said (Pv20). 85."You (A) mix (Pm26) the cowpea flour and palm oil (G), 86.then you (A) steam-cook (Pm27) for hours $(\mathbf{X})$. 87.You(S) think (Pme11)// 88.you (Pr/Cr) can ever get (Pp3) just the cowpea flour (Pd/At)? Or just the palm oil?(Pd/At)"

89."What are you (Sy) talking (Pv21) about? (Ct)" (Vb)90. Father Amadi (Sy) asked (Pv 22).

91."Religion and oppression," (Vb) 92.Obiora (Sy) said (Pv23).

93."You(S) know (Pme12)// 94.there is (Pe1) a saying(X) //95.that it $(\mathbf{T})$ is $(\mathbf{P i 3})$ not just the naked men $(\mathbf{V})$ in the market (Cl) //96.who (Cr) are (Pi10) mad? (At)" (Vb) 97.Father Amadi (Sy) asked (Pv24). 98."That streak of madness $(\mathbf{C r})$ has returned $(\mathbf{P i 1 1}) / /$ 99.and is disturbing $(\mathbf{P m e 1 3})$ you $(\mathbf{P h})$ again $(\mathbf{X})$, okwia?"

100.Obiora (Be) laughed (Pb14), //101.and so did (Pb15) Amaka (Be), in that loud way $(\mathbf{C m}) / / 102$. it $(\mathbf{C r})$ seemed (Pi12) //103.only Father Amadi (A) could get out (Pm28) of her (CI).

104."Spoken like the true missionary priest, Father," 105.(Vb) Amaka (Sy) said (Pv25). 106."When people (Sy) challenge (Pv26) you (Rv), //107.label (Pi4) them mad (V).

108."See (Pme14) how (Cm) //109.your cousin (Be) sits (Pb16) quiet $(\mathbf{C m}) / / 110 a n d$ watches? (Pb17)" (Vb)111 Father Amadi (Sy) asked (Pv27), /112./gesturing(Pm29) to me(B).112. "She (A) does not waste (Pm30) her energy (G) //113.in picking (Pm31) never-ending arguments (G). 114.But there is (Pe2) a lot (X)//going on (Pcc1) in her mind (CI), 115.I (Sy) can tell (Pv28)."(Vb) 